\title{
Interactive Media Art: the Institution Tells a Story. The Center for Art and Media Karlsruhe
}

\author{
Media Art Interactivo: \\ la Institución cuenta una historia. \\ El Centro para el Arte y Media Karlsruhe
}

Sónia Alves

Interactive Media Art Researcher

Fecha de recepción: 2 de mayo de 2014

Fecha de revisión: 11 de julio de 2014

Para citar este artículo: Alves, S. (2014): Interactive Media Art: the Institution Tells a Story. The Center for Art and Media Karlsruhe, Icono 14, volumen (12), pp. 181-205. doi: 10.7195/ri14.v12i2.709 


\section{Abstract}

Interactive Media Art has been scrutinized under several approaches. It is though hard to achieve consensually a clear definition or conceptualization of this term. What I propose here is to follow a case study of an institution, the Center for Art and Media Karlsruhe, whose contributions for the development of this art form are unique and represent a continuous and profound achievement to the art world. At the same time this research calls the attention for another way to look at the developments of Interactive Media Art by considering the institutional investment in the production of art. Simultaneously I will show that there is a pragmatical, educational and pedagogical line of research in the history of Interactive Media Art that has not received much attention until now.

Key Words: Interactive Media Art - History - Center for Art and Media Karlsruhe - Institutional Practice in Art - Artistic Production - Educational Practice - Science Technology - Interactivity

\section{Resumen}

El "Interactive Media Art" ha sido examinado bajo distintos enfoques. Sin embargo, resulta dificil lograr una definición o conceptualización consensuada de este término. Este artículo propone seguir un estudio de caso de una institución, el Centro de Arte y Medios de Karlsruhe, cuyos aportes para el desarrollo de esta forma de arte son únicos y constituyen un logro continuo y profundo al mundo del arte. Al mismo tiempo, esta investigación llama la atención sobre otra forma de mirar los desarrollos de Interactive Media Art considerando la inversión institucional en la producción de arte. Simultáneamente, se demostrará que hay una línea pragmática, educativa y pedagógica de la investigación en la historia del Interactive Media Art que no ha recibido mucha atención hasta ahora.

Palabras clave: Media Art Interactivo - Historia - Centro para el Arte y Media Kalsruhe - Práctica Institucional en Arte - Producción artística - Práctica educativa - Ciencia - Tecnología - Interactividad 


\section{Introduction}

The research in the field of Interactive Media Art has been growing in the last few years. However still there is a lot to be grasped and analyzed within the context of its history, developments, and the so many ways of its appearing. In this context what is proposed is to approach the history of such an artistic expression considering one of the pioneering institutions to embrace it as a significant part of its structuring: the ZKM I Center for Art and Media, Karlsruhe ${ }^{1}$.

Even though the role that institutions have been playing within the context of Media Art production is of crucial importance to the supporting and creation of such art, they usually receive a less central place when analyzing the history of this artistic expression. This possible frame of analyses will lead the historicization of Interactive Media Art in this paper. More, this path will bring up a new light on the connections between Science, Art and Interactivity once, in the case of ZKM, the Science Museums would have, at first, an important role in defining the production of Interactive Media Art, just like it will be seen when analyzing ZKMs artistic defined strategies, for this subject, until the MultiMediale 2.

Since the beginning, ZKM had been following the wish of being a pioneer institution in the development of Media Art resulting from an interchange between Science, Technology and Art. Interactive Media Art was not planned as an artistic investment, at least not under this nomination. However it would appear as a consequence of the search of bridges between the production and reception of Media Art artworks.

Never before the ZKM had an Institution dedicated so much importance to Interactive Media Art. That is why it is important to document the history of such practices in the context of the Institution(s).

There is no shortness of examples of Interactive Media Art that would have not been produced if they were not supported by an institution. The demanding's and the cost of such artistic productions tend to be institutionally bound. Or at least, tended to be institutionally bounded during the 1990s. For its outstanding sup- 
port and contribution to the development of Interactive Media Art, for its contribution to a significant part of its History, ZKM takes a central place in this paper.

The choice of this specific institution is also based on the fact that, thought the ZKM has one of the biggest (if not the biggest) Interactive Media Art collections in the world, it was never deeply analyzed how this collection originated and developed.

\section{Methods}

I will start by contextualizing theoretical approaches to Interactive Art in a chronological way in order to create a time line that can anchor what was happening in the 1980s and 1990s. This will help to understand how there was still a significant absence of a theoretical approach to Interactive Media Art in the time that ZKM was founded and it will also contextualize the features of the research that was followed by the team of ZKM when they were trying to find the best fitting structure for the institution.

On one hand side the research dealing with ZKM history and the circumstances that would lead to the development of Interactive Media Art will be focused on the documentation that was published at the time of the foundation of the Center, and that consists of a conceptualization; several reports on different subjects connected with the different themes of interest for the institution; and the report, appeared latter, on the changes that were to be made to the original concept.

Though the ZKM is an institution that has dwelt, since the beginning, with a wide spectrum of research in the area of new media cultural, scientific and artistic production, I will center my line of work in the subjects directly connected with the emergence of Interactive Media Art.

My aim is to revisit the history of ZKM, but while doing so my purpose is to make clear how the settlements that lead to the known forms of Interactive Media Art produced in ZKM were germinating since the foundation of the institution. Indeed the intended is to answer to the question: how did the ZKM started to produce Interactive Media Art and why?

ICONO14 | Año 2014 Volumen 12 N² 2 | ISSN: 1697-8293 | DOI: ri14.v12i2.709 
I will therefore follow the developments of a didactic conception presented in one of the thematic areas of ZKM, the «Media for the Citizens», and make clear that it lead to the emergence of Interactive Media Art.

On another hand side this search through the historical documents of ZKM brought to light the fact that certain Interactive Media artworks that appeared in the context of the Museums of Natural Sciences were of significant meaning for the developments of Interactive Media Art in ZKM. This opens a possibility to reflect narrowly on the role of the Museum and the new ways of dealing with Science and Art in the same technological context, while reflecting either on the means of creating new relations with nature and natural phenomenon's or on the creation of new objects and fields of experience for a museum's visitor. This approach allows to think about the History of Interactive Media Art from a less common perspective.

I will focus my analyses in the first years of ZKM because it is at this time that the relations to the production of Interactive Media Art are established. Therefore the chronological focus of this paper will be settle between 1988, the date of the presentation of the first concept, and 1991, the date of the MultiMediale $2^{2}$ and the date when the Institute for Visual Media is founded and structured into specific directions that would change significantly the course of the previously thought ${ }^{3}$.

\section{Results}

\subsection{A moment in time}

In the 1980s the sphere of what is nowadays defined as Interactive Media Art, was a promising one but one affected by a varied array of constant developments. Brought specially into light within the context of digital media, interactivity, as a practice established in the context of Media Art, would receive a big hype during the 1990s. But before that some institutions were already dealing with such conceptions, even if they wouldn't appear under such nomination.

One of the first theoretical approaches to Interactive Art, coming from the field of Art History, appeared in the 1970s (Popper, 1975) and would refer specifically to

DOI: ri14.v12i2.709 | ISSN: 1697-8293 | Año 2014 Volumen 12 № 2 | ICONO14 
a new status of the spectator ${ }^{4}$ that would assume centrality in the defining of this art form. Other theoretical approaches to Interactive Art may have been made, but it was only around the middle of the 1990s that Interactive (Media) Art started to be addressed and theorized more consequently ${ }^{5}$.

Considering the case of ZKM, and after analyzing the different documents that inform about its grounding reasons there is none where a reference to such analyses or approach appears. There are references to ways of experimenting with artworks but never under the nomination of Interactive Art. This shows how Interactive Media Art was yet to find a territory of its own within the artistic conventions. As already referred these path would start to be built around the middle of the 1990s and, since a few years, it has regain the attention of researchers.

Publications such as the ones from Brouwer \& Mulder (2007), Steifert, Kim \& Moore (2008), Sommerer et al. (2008), Candy \& Edmonds (2011) or Kwastek (2013), have been consequently showing aspects as well as possible ways to approach and analyze Interactive Media Art, while contributing to its historicization. These authors center their approach in a taxonomy for Interactive Art forms; elaborate classifications; identify features; chronologies; etc. but leave behind the role of the institutions that made of Interactive Media Art one of their main focus.

By following the direction the quest is to know about the reasons that underline the choices for such an investment, one that reflects profoundly an awareness of a specific cultural context, and the wish to have, at the same time, an active role in it. That is why the ZKM takes a central place in my reflection. It may well be that there is no other institution following this parameters.

Officially born in 1989 under the status of a Public Foundation the project for the Center for Art and Media Karlsruhe, had been in development since 1985. It was the result from a proposal from the Bureau of Culture of the City Hall together with the government of the state of Baden-Württemberg. Both would like to see an improvement in the structures and in the politics dedicated to possible future investments in Karlsruhe, and would like to answer to the need of requalification of a specific part of the city. In the same year a committee, thematically centered

ICONO14 | Año 2014 Volumen 12 N² 2 | ISSN: 1697-8293 | DOI: ri14.v12i2.709 
in Art and Media, was created and it would be responsible for the conception of the Center. The project that they proposed in 1986 would still be under discussion in 1987. This same year there was a new formation of the working group which would define the name for the Center, ZKM I Center for Art and Media Karlsruhe, and redefine the tasks that were to be taken. From this work emerged the Concept dated from 1988 (Konzept '88), were it was finally established the structure for the future Center. Since the beginning it was defined that the ZKM would have three main subject areas: «Image», «Music», and «Media for the Citizens» ${ }^{6}$. And all of them would develop under the purpose of creating and showing the relations of Art to Science and Technology.

Just like it happened in the context of the general conception of ZKM, to each of the three referred thematic areas was assigned a research committee that was composed by a group of specialized figures attached to cultural and research institutions from Karlsruhe or its surroundings. This committee would report on the importance and potential of these areas and delineate a possible array of interest and intervention. Because this paper is centered in the area «Media for the Citizens», I would like to refer that its committee was constituted by representatives from the Fraunhofer-Gesellschaft, the Institute for Systems and Innovation Research, the Museum of Natural History of Karlsruhe, the Foundation from the State's Museum for Technic and Work of Mannheim, the University of Karlsruhe, the University for Cooperative Education of Karlsruhe, the Chamber of Industry and Commerce, the Adult High School, the Confederation of German Trade Unions and an Art Historian. (Heck et al., 1988: 38-39) - For the areas of «Image» and «Music» the committees were more subject oriented ${ }^{7}$ but always composed thinking about interdisciplinarity - .

By naming such a heterogeneous group of institutions to work within the area «Media for the Citizens» one can question if there was really an objective planning that would be put forth. In any case this ensemble of institutions should find an effective way to get closer to the citizens within the working frame of the encounter of Science, Technology, and Art. The desire to be directly connected with the citizens pointed already towards the direction of Interactive Media (though the concept was never really used in the early stages).

DOI: ri14.v12i2.709 | ISSN: 1697-8293 | Año 2014 Volumen 12 № 2 | ICONO14 
Besides production, research would also be transversal to the three main thematic areas of ZKM. This should be centered on "artistic, aesthetic and pedagogical implementations of new technologies in a creative way and not simply as technical procedures." (idem: 12) The initial organization of ZKM included also the stimulation of training and a wide array of presentation of results, either in a museological context or by means of public communications and discussions taking place in the form of forums (idem, ibidem). These features were included in the area «Media for the Citizens».

\subsection{Art, Science, Technology and the Citizens}

The role of Art, Science and Technology was present in the concept of ZKM since the first moment. Karlsruhe had been a dynamic pole of research as well as of artistic creation and presentation, since a long time. Institutions such as the Academy of Fine Arts, the Conservatory of Music, the City Gallery, National Museums, the Badische Kunstverein, the state's Library and the state's Theater, the Technical University (one of the oldest of Germany that includes the most known Faculty of Informatics in Germany), the University of Applied Sciences, the University of Cooperative Education, the Fraunhofer Institute, the Nuclear Research Center, the College of Education, the Chamber of Industry and Commerce, the Chamber of Trade (idem: 10), among others, contributed to the perfect environment for the development of scientific research, technologies and art. That was one of the reasons justifying the need to create the ZKM in order to bring this developments closer to the city live and to the citizens, while inscribing them within a changing cultural context were technology was taking a central stage. An awareness of development that ZKM should be able to grasp by centralizing all the different ways of knowledge that was being developed and produced. But it should also be able to synthetize it, and contribute to innovativeness by making use of it. While fulfilling this demands ZKM would have Art as its main core, and it would assume the role of a platform of intersections open to a polyvalent and interdisciplinary production of artworks that would result from dialogues between sciences and technologies. Moreover the ZKM was also projected to be the place for citizens to learn with technologies and to experience with technologies in a very narrow way with the arts.

ICONO14 | Año 2014 Volumen 12 N² 2 | ISSN: 1697-8293 | DOI: ri14.v12i2.709 
This purpose was described in the Konzep ' 88 and resulted from a research on the relations between Art and Media Technologies and on how the latest had been affecting the content and the form of Art in an essential way, "from perception to the social and communicative perceptive capability of beings." (idem: 5) Because the spreading and availability of New Media have systematically altered the relationship from subjects to Art and to Technology, and because, at the time, it was clear that we were in a context of profound changes due to the technological developments centered in the computer, the aim to focus and reassert the importance of the proximity between Art and Technology intended to reach not only the expertise worlds of Science and Technology but everybody: "Art, in addition to technology, has become an integral and determining part of the everyday life contexts, of the everyday culture." (idem, ibidem) In this conceptual environment technological developments were approached as creative possibilities that could be used in the context of representation through image or in music, integrating a special challenge (idem, ibidem).

The fact that the computer, at the time one of the newest technologies (at least within the context of mass consumption), combined the possibility of being used either by the scientist or by the artists, made it be seen as the tool that allowed the emergence of a vast array of "perspectives between art and sciences." (idem, ibidem) Such would sustain the need for a systematic research aimed to combine artists, scientist and technicians "in a lively and free exchange." (idem, ibidem) In the end the concept that had been put into practice in 1966 by the group of artists and engineers E.A.T. (The Experiments Art and Technology Group) was finding a refreshing revival by the end of the $1980 \mathrm{~s}^{8}$.

The relations between Art, Science and Technology were continuously advanced as the main focus of the ZKM by its different leading figures. Named as the first director for the Center, Heinrich Klotz would express, in 1989, his wishes that the ZKM had as aim "to bring art and new media together in theory and praxis (...) to make a synthesis from art and media technologies (...) centered on the critique of a media euphoria." (Klotz, 1989: 3) But, in the same context another variant would be introduced to the equation: the role given to the citizens, whose reference is also common and frequent. The ZKM would "provide artists and scientists as well as the

DOI: ri14.v12i2.709 | ISSN: 1697-8293 | Año 2014 Volumen 12 № 2 | ICONO14 
interested citizen, with facilities and instruments in order to achieve this objective." (idem, ibidem) Something that Gerhard Seiler, the City Mayor back then, would assert: "... the ZKM represents an opportunity and an enrichment for the art and science (...) and, not the least, for the citizens" (in Späth, 1990: 7). He would continue:

“...the planned Center for Art and Media defines as its own mission (...) to implement artistic ideas with the help of technologies. The purpose of the future facility will be the possibilities of use of new technologies to research in art and sciences, and to promote the development of artistic experiments, education, and teaching. In this context it is indispensable the cooperation between art, science and technology. The planned center will therefore also fulfil the requirements of a research institution. But, also as an innovative cultural center it has, simultaneously, the duty to show the interested citizens the results of the artistic and scientific work, and to be connected with it by means of the educational range." (Seiler in Klotz, 1990: 5)

A statement that stresses the urgent need to develop a specialized education in the area of Technology, Art and Aesthetics, one that would make possible to keep up with the parallel research in Science. The ZKM had, back then, in mind that this education should be specialized, and available to all the citizens. Such also justifies why its initial structure was so focused on the development of didactic, educational, and pedagogical programs in the area of New Media. This aimed to diminish the distances between public, artist and scientist and it would be so meaningful that it was given the same importance than image and sound and characterized the program for the area «Media for the Citizens».

The reception of an artwork or a cultural production made in ZKM, was to be treated as part of the appearing of new artistic forms and concepts. The role of mediation was, therefore, brought to the center of a long artistic program that would have to deal with visual media and audio technologies, but also with the technological developments to which the general citizen needed to gain access to as well as understanding.

The thematic area «Media for the Citizens», would have to manage this vast teritory. Just like Lothar Späth, the prime minister of the state of Baden-Württemberg at 
that time, announced, the ZKM aimed to be an initiative of meaningful relevance for the arts and for the sciences whose goal should be to create the opportunity for the combining of Art and Technology to be experimented and used in the creation of new artistic impulses. The point of departure should be research and developmental projects, education and seminars, as well as a broad overture to the different possibilities of Media Technologies, in the end a constant grappling of Art and society (1990: 3).

However what comes forth from the Konzep ' 88 , while reading the dedicated matters to the area «Media for the Citizens», is that there were still difficulties in achieving a consensus for what would really mean the relations that would be established between artworks and public. In this first approach to the thematic there was a strong social purpose underlining the conceptualization. Emphasis was put on the need to prepare the citizens to embrace the challenges of New Media. Therefore the already referred need to create an educational program in the area of Technology, Art and Aesthetics that would be available for everybody: the artists, the scientist and the general citizen, was of central importance. The predisposition to a didactic approach (Heck et al., op.cit. 6) was combined with the purpose of developing " $a$ fruitful counter-current flow between audience, artists and scientists, one that contributes for each of them to receive information, to exchange and learn from each other." (idem, ibidem) And it was complemented by the intentions in creating new services in the area of Art and Media as well as of mediation, in the context of the new art forms. The propensity towards education considering the social consequences of the technological developments was indeed the expression of a cultural engagement with social competences, just like expressed in the Konzep '88:

"The Center for Art and Media is focused on human techniques, because the aesthetic approach is one of the immediate life-expressions of the human spirit that will be developed as the technologies evolve. This is one of the central concerns of ZKM. That's why it offers a vast array of possibilities that handle in a free and playfully, experimental and creative way with the technologies available to the artists and to people in general." (ibidem: 8)

With this statements it becomes clear that there was a strong emphasis in the need for courses, lectures, talks, workshops, structures of information, etc., but

DOI: ri14.v12i2.709 | ISSN: 1697-8293 | Año 2014 Volumen 12 № 2 | ICONO14 
these activities would ran in parallel to the creation of artworks. Considering the statement made to this subject, and that we will follow under, it is comprehensible to assume that the artworks that were planned to have interaction features were seen as a continuation of this didactic strategy.

The interaction with the artworks was to have an existence within the context of a specific structure of the area «Media for the Citizens»" ${ }^{9}$, namely the Forum. Here there was a reference to a possible display of an historical collection of Art and Technology, selected from the areas of image, music and communication, and including space installations, artificial and sound environments. It was programmed that the Forum would count with new ways of showing Media Art, and that it would be conceived as a space for experiencing: "there will be given special importance to the idea of 'touching the exposed objects' and to de development of 'actions with the exposed object."' (idem, ibidem: 26) So, the Forum would be the structure where the presented artworks would effectively be put in a situation in which they could be touched and experienced by the visitors. The introduction of this feature in an exhibition context was seen as an effective way to promote and encourage the citizen's handling and understanding of technologies. The concept for this 'do-it-yourself' areas, dedicated to the use of simulators and apparatuses of demonstrations (intelligent games, moon landing, navigation in hard circumstances, simulations from traffic), for example, intended to help the acquaintance of the citizens with New Media, in a playfully way (Behringer et al., 1988: 146).

Such ideas are made clear when reading the study, made by Bernhard Graf, from the Institute for Science Museums in Berlin, and where he states the fundamental principles (Graf in idem, ibidem: 147-153) for the main structures of the «Media for the Citizens» thematic area. In this case he considers that the exhibitions should have a central role in the rapprochement to the visitors "once they are privileged carriers of a message and they can really bring the public closer to the technologies" (idem, ibidem: 148). However he calls the attention to the fact that the didactic dimension of the employment of media in a museum exhibition was something that, back then, was hardly existent. In what concerns the public experience with the object in the museum context he would, therefore, suggest to be put an emphasis in the different electronic media that would have a double use, either

ICONO14 | Año 2014 Volumen 12 N² 2 | ISSN: 1697-8293 | DOI: ri14.v12i2.709 
in the museum context or in the everyday life context of each individual. He also sustained that a museum of New Media should provide exhibitions where the visitor would be given the possibility to be activated, that is, the use of the concept 'hands-on', the stimulation of a direct reaction from the public. To further research this topic Dr. Graf suggest that the ZKM committee take a look at some of the technical and Science Museums that were offering specific possible ways for the public not only to view but to relate actively with the artworks being exhibited. As examples he refers the Ontario-Science-Center, in Toronto; the Exploratorium, in San Francisco; and the Cite des Sciences et de l'Industrie - la Villette, in Paris. From this institutions he would stress the example of the Exploratorium as the one where he recognized a closer relation to the pretended program for the ZKM (idem, ibidem: 148-149).

In the same appendix Achim Lipp, from the Kunsthalle Hamburg, would also suggest that there were possibilities for interaction that could be viewed in the context of the constitution of a Media Museum that had not yet been approached, for example, by thinking closer about a proximity in the exchange of cultural life and the area of information, what could consider inclusively the introduction of animations that would invite to spontaneous handling of digital object (idem, ibidem: 155). Following this logic he suggested the creation of a project centered on the computer, one that would allow intervention combining didactic, pedagogical and mediation strategies to relate with art and to the questions that are usually carried out with this quest. Another suggestion that he would made would be to make an intervention based on computer games and show, for example, Atari (Lipp in idem, ibidem: 163).

So there was indeed, since the beginning, and within a vast complex didactic planning in the context of «Media for the Citizens», an expressed whish that interaction with the artwork would take place. This desire would gain a clearer shape with the presentation of the changes to the Konzep ' 88 made by Heinrich Klotz, in 1989.

The new proposal of Klotz maintained the main organization already defined in the previous concept. But Klotz would relieve the ZKM of the planned strong pedagogical approach by including the creation of a University for Arts and Design, whose purpose would be to deal with the professionalized formation and educa-

DOI: ri14.v12i2.709 | ISSN: 1697-8293 | Año 2014 Volumen 12 № 2 | ICONO14 
tion of personal and of citizens (students) that were to be working and studying the new emergent technologies in their different aspects, either technological or aesthetic. The University would have the role to teach, for example, video, computer graphics, laser and holography techniques and it would be responsible for education and research that exploited the potential of new technologies. Though planned to cooperate with the ZKM, and to have the same head director that the ZKM, the University was conceived as an independent institution.

In parallel to this changes Klotz conceived the creation of a new museum for the ZKM, the Museum for Contemporary Art, that would bring closer the traditional and the Media Art forms not in an historical way but by showing the work of new artists working with media.

The thematic structure of the ZKM would continue to be focused on «Image», «Music», and «Media for the Citizens». In the latest were included:

1. Computer Laboratories and Studios (especially open to specialized citizens) ${ }^{10}$;

2. The Media Theater ${ }^{11}$;

3. A collection (of video art, holography, electronic music, media art) and documentation departments;

4. A Museum Forum constituted by two different museums, the Museum for Contemporary Art (dedicated to the showing of the crossing developments between the traditional arts and New Media Art forms) and the Media Museum where all the program for interactive experiencing would take place.

According to Klotz the Media Museum would function in a narrow relation with the computer laboratory and the studios (the areas of research and development of artistic production) and it would be dedicated to exhibitions that presented a history of media in the different media categories. It would be directed towards observation and experimentation and the exhibitions would allow the public to participate: "at the same time the public can take part. It would be didactic and psychological problematic to leave the public of a media museum amidst a mix of apparatus and a firework of effects." (Klotz, 1989: 6) To fight against this last pos-

ICONO14 | Año 2014 Volumen 12 N² 2 | ISSN: 1697-8293 | DOI: ri14.v12i2.709 
sibility Klotz conceived an exhibition that would allow the visitors to experiment and interact with the different media. But this was still a very simple concept of interactivity where the visitors would play in order to understand the functioning of the technical means of reproduction. That would be possible in the context of the impression technics, that is to say engraving or similar experiments. What was, indeed a process of recreating the environment in a workshop, more that an artistic approach to the subject. Apart from these didactic spaces Klotz conceived a room for the arts of spectatorship (video and film, computer graphics, holography and laser). According to the director of ZKM they should be shown in an animate experience through the use of manipulatable instruments. He suggested, for example, that it could be possible to "draw, for example, a house, by using computer programs usually available to architects." (idem, ibidem) This exhibition would include the showing of media environments inspired in the concept of the Gesamtkunstwerk. In this case Klotz suggests a room of big proportions were the different media could be combined to create an effect resulting from "electronic music, laser, video, light." (idem, ibidem) The simulation media would complement this concept of exhibition focusing the methods of proximity put forward with 3D simulation techniques that, according to Klotz, would eradicate the difference between observer and image, artwork and visitor. He imagined several possibilities of spatial navigation just like for example in a city, or a flight in the Grand Canyon.

We can realize that, with this exhibition program there was still a strong didactic purpose characterizing the proposals for Media Museum. But such conception was never realized in the ZKM. In some exhibition afterwards there would be works based on the possibilities of computer graphics that would be close to this criteria of Klotz, but they illustrate, at the same time, possibilities to recreate virtual spaces and virtual realities, being therefore, at the time being (around 1993), a process of the artistic research taking place in ZKM. Fundamental in the proposal of Klotz is the constant attempt to create strategies that put the citizens dealing/ interacting with media, understanding its possibilities, features, and capacities. Characteristics that were also encountered in the Interactive Media Art research by then.

DOI: ri14.v12i2.709 | ISSN: 1697-8293 | Año 2014 Volumen 12 № 2 | ICONO14 


\subsection{The formulation of Interactivity in Media Art}

It is clear by now that, in what concerns interactivity and the aspiration to create interactive possibilities in the realm of media, that had the aim to reach the citizen, the ZKM had kept their working line in development, since the beginning. But, even Klotz seemed to have difficulties in creating the bridge between the technicality of the different media and the possibilities of dealing with this quest in a more artistic way, by embracing the creation of Interactive Media Art all along. Klotz had conceived a museum for Contemporary Art centered on Media Art, but had not yet envisioned the possibilities of Interactive Media Art besides a didactic context. This would definitely change with the MultiMediale 2, in 1991, but it was a change that evolved from others factors.

It may be that one of the causes for the approach described until now was a general lack of knowledge in what concerns these art form, and that makes sense back then, or that the examples of Interactive Media Art known by the ZKM (as far as the documentation leads us) were first researched with a didactic approach in mind. An aspect that may have blinded other possibilities of use, at first sight. Eventually such line of thinking can be cleared by analyzing the source of the ideas of interactivity present in the different reports that underline the original concept of 1988.

The Konzep '88 appeared with the contribution of the different reports written by the several committees that traveled to a significant amount of institutions (twenty two stations), from different Countries (EUA, Canada, and France) analyzing and evaluating the way of producing and showing art, and how these could be of relevance or inspirational for the development of the project ZKM.

Such a purpose contributed to a very close research within the area of Science Museums, considered as the kind of museum where the citizens could experiment, touch and relate actively and interactively with media, and media installations ${ }^{12}$.

The travels to the different institutions abroad would consider all the aspects of media in relation to image and sound as well as the practical mediation through

ICONO14 | Año 2014 Volumen 12 N² 2 | ISSN: 1697-8293 | DOI: ri14.v12i2.709 
technologies, so common in the Science Museums (experimenting, touching, and doing).

The different comittees have visited, for example: the Media Laboratory from the Massachusetts Institute for Technology (M.I.T.); the Center for Advanced Visual Studies from M.I.T.; Pixar (Lucas Film) in Los Angeles; the Computer Science Division (EECS) in the Department of Computer Graphics from the University of California in Berkley; the Computer Systems Research Institute, from the University of Toronto; the Center for Computer Research in Music and Acoustics (CCRMA), in the University of Stanford; The Computer Museum in Boston; The Kitchen in New York; the Museum of Holography in New York; The Exploratorium in San Francisco; the Ontario Science Center in Toronto; the IRCAM (Institut de Recherche et Coordination Acoustique/Musique) in Paris, the Cité de Sciences et de l'Industrie, also in Paris, among others.

To each of these institutions it was created a report where several aspects were to be evaluated. Namely the history of the institution; the area of work; the working personal; the technical aspects; the subvention; and how significant they would be for the constitution of the ZKM. In what considered the approach to Interactive Art experiments there were references to the interactive possibilities of sound (for example, by pressing a button) coming from the Center for Computer Research in Music and Acoustics (CCRMA), in the University of Stanford, considered to allow experiencing sound in a new way; and specially references about the art mediation and experience with technologies happening in Science Museums: The Ontario Science Center, in Toronto; the Exploratorium, in San Francisco; and the Cité de Sciences et de l'Industrie, in Paris.

Besides the artist-in-residence program, that was considered to be of value to the project of ZKM, there was a vivid reference to the Ontario Science Center, a museum created in 1969, dedicated to sciences and technology, and that since the beginning had the dictum "Let the visitors touch the exhibits." (Behringer et al., 1988: 119) There the visitors could not only see the exhibitions but also experiment, play and interact with the different exposed objects/situations. The presence of indications for use of the works seemed to be something that also needed to be kept in mind for

DOI: ri14.v12i2.709 | ISSN: 1697-8293 | Año 2014 Volumen 12 № 2 | ICONO14 
the ZKM, as well as the realization that such a program attracted a big amount of young visitors. For the ZKM area of «Media for the Citizens» it was stated that would also be important to consider the mediation practices of this museum.

The same features would be recognized in the case of Cite de Sciences et de l'Industrie, in Paris. Described as "an instrument of communication between a wide public and a place that gives access to the industrial, scientific and technical contemporary culture, expositions, documentation, public debates, workshops" and where the direct experience of each off the participants was lively combined (ZKM, 1989: 10). But the most fruitful influences came from the Exploratorium, in San Francisco, also a museum dedicated to sciences, technologies and perception, funded in 1969. There the exhibitions were mainly focused on the creation of an active relationship with the visitors and stimulated the engagement with experimentations that would allow, for example, the illustration of natural phenomenon through real life effects in real time, while offering an enthusiastic way and opportunity to learn. Thematically the Exploratorium was dwelling with sound, light, colour and heating, that is, with a framework of biology and physics. In this case the committee was also impressed with the seminar rooms, the education program, and the artists-in-residence program, whose purpose was to create presentations for the understanding of the world. The artworks would allow the establishment of a relation between nature and culture, and were created considering the viewer's activation.

The contact with this institutions, specially the Exploratorium, allied to the didactic purposes defined by Heinrich Klotz for the «Media for the Citizens» area, would be specifically reflected in the program of the MultiMediale 2 (1991), whose invited institution was the Exploratorium. A selection of works that called the attention for Natural Sciences, Art and Perception was brought to Karlsruhe and shown in an emancipatory museological context. Something that had not yet happened in the history of ZKM, just like we can see by analyzing the previous exhibitions organized by the Center, just like the MultiMediale 1 (1989), and before.

In what concerns the MultiMediale 2 the artworks had all been produced in the context of the artist-in-residence program of the Exploratorium. Hilde Hein, sustains that this was the first time that such artist-in-residence program was

ICONO14 | Año 2014 Volumen 12 N² 2 | ISSN: 1697-8293 | DOI: ri14.v12i2.709 
presented in Germany. And that several from the media artists present in this show have then and there started their carriers as well as bringing the principles of interactivity to the context of Media Art (1993: 8) ${ }^{13}$.

Also in the MultiMediale 2 there were other interactive artworks dealing with questions of virtual navigability and simulated environments, or artificial worlds, presented in installations. All of them were to be used by the public. Artworks like The Karlsruhe Moviemap (1991), from Michael Naimark, inspired by the Aspen Movie Map (1978), or like Weinbrennres Traum (1991), were also presented and are nowadays among some of the examples of the Interactive Media Art collection of the ZKM. Also shown in the MultiMediale 2, it was The Legible City (1989-1991), from Jeffrey Shaw, an artwork that would deepen the challenges of Interactive Media Art. All of them contributed to the definition of a specific tendency in the Interactive Media Art of the 1990s, and contributed to the creating of new foundations for a more livable experience of the museum, without being necessarily with specific educative or didactic purposes. The art followed its own way, the spectator found its new place.

After the MultiMediale 2, the first exhibition of ZKM to have Interactive Media artworks, Heinrich Klotz invited Jeffrey Shaw to work in the Center. There he would found the Institute for Visual Image and create a program, including artist-in-residence program, that would be central for the development of new ways of interaction with the artwork. At the same time, reflecting and acting on the challenges that the technological developments demanded and presenting a constant up-to-date with cultural, artistic and theoretical approaches to New Media and interaction, Shaw's line of work, presented in the following MultiMediale $(1993,1995,1997)$ would be central to bring ZKM to the world stage of Media Art and Interactive Media Art production and presentation.

At the same time, what had been previously thought as the area «Media for the Citizens», ended up by coalescing in the structure of Media Museum and other structures of presentation just like the Media Theater or the Media Lounge that would assume each their specific programming. The idea of Media for Citizen would be spread in all the different sections of ZKM, not centralized in one department.

DOI: ri14.v12i2.709 | ISSN: 1697-8293 | Año 2014 Volumen 12 № 2 | ICONO14 
Media Museum would be focused on the presentation of new ways of experimenting with image, virtual worlds; in accessing interactively new visualization systems and possibilities, navigability, etc., in the end showing the production of Visual Media Institute and the results of research with different cooperation's made in the context of the developments and research of Art, Science and Technology.

\section{Conclusions and discussion}

\subsection{Please, touch the art!}

The Center for Art and Media Karlsruhe is quite known in the area of Media Art and one of the most, if not the most, important institutions dedicated to the creation of Interactive Media Art, having one of the biggest, if not the biggest collection of Interactive Media artworks. This paper enlightened the grounding context for this developments in a time were the possibilities of New Media seemed specially promising. Part of the prior historical moment of the ZKM deals with making the promising realizable. In this sense the persistence of all those involved with the project led to the success of Media Art practices and to the enrichment of contemporary culture and art. The initial, very politically influenced, desire and ideas to bring the ZKM closer to the citizens (which would be financed with public money) became a source of research, development, interdisciplinarity, all conformed in the universe of art.

The institutional landscape of Karlsruhe, the politicians, the art institutions as well as the researchers of Science and Technology managed to create, in the second half of the 1980s, a project that would be the most updated in what concerned the structures dealing with Art and technological implementations, and the structures dealing with a strong desire of not remaining in a solipsistic state caused by the incapability to reach the public.

By persistently not letting go of the nuclear conception for ZKM, but adapting it to circumstances of possible realization that always managed to balance what was planned with what was possible, Heinrich Klotz would lead a more effective possibility to bring the public closer to New Media and Art. In what concerns the

ICONO14 | Año 2014 Volumen 12 N² 2 | ISSN: 1697-8293 | DOI: ri14.v12i2.709 
history of Interactive Media Art the change happened when a planning based on a didactic intervention was dropped in favor of one where the mediation became based on interaction, and when interaction became a feature of the artwork. In terms of presentation such a process was definitely achieved in the context of the MultiMediale 2, in 1991. In this path, that was also one of definition for Interactive Media Art, the contact with several Science Museums would help ZKM to achieve the so desired purpose of bringing the citizen closer to the interplay between Art, Science and Technology in a contemporary manner, also adequate to the reflections about Art, allowing the visitor to be confronted with the artistic situation as well as to become part of it. To touch the artwork became a multidimensional experience that has extrapolated the frontiers of the cultural, didactic and pedagogical programs, while it could also be considered part of it. That is what the MultiMediale 2 ended up by presenting: a new form to experience art in the institutional context, resulting from the constant institutional search in finding the best way to be closer to the public, and to offer the citizens new experiences with Media, inviting them to reflect and act. The role of such Science Museums that were, at the time, already working with artists, is profoundly meaningful for the history of Interactive Media Art, and for Interactive Media Art in the context of ZKM.

Notable is that with this research another relation with the development of the Institution of Art, the museum, is established. With it I open the subject to another reflection about Interactive Media Art.

Already in the sixteenth and seventeenth centuries museums allowed their visitors to touch the objects, among other reasons the purpose was to "supplement sight by touching, as a means of discovering the traits of the object on display. Hearing and smell might also be used for this purpose. Such multisensory investigations were supported by contemporary scientific practice." (Classen, 2005: 276) A reference to the use of multiple senses to investigate the museum seams to carry on with it the idea of comprehending the nature of what is being shown. Just like the masterminds of the ZKM have wished since the beginning by insisting on a didactic approach - to understand by touching, and experiencing with the different techniques.

DOI: ri14.v12i2.709 | ISSN: 1697-8293 | Año 2014 Volumen 12 N² 2 | ICONO14 
The search for the sense of touch, so important for Interactive Media Art, just like Huhtamo (2007) has already sustained, would allow therefore to access the technology, comprehend it, use it and put it into praxis. This knowledge leads also to the comprehension of culture, to the familiarization with technological realities and uses that go far beyond the museums experience.

Classen tells us also that "the sense of touch, was perceived as annihilating not only space, but also time. This oft-perceived ability of touch to bridge space and time gave it a special value in the museum settings, where visitors were separated by considerable spatial and/or temporal distances from the cultures of origin of the many objects displayed." (ibidem: 278) In the case of Virtual Art it can destroy the uncanniness feeling and making it more human, it can allow the visitor to access the mysterious powers of technology devailed by Art, just as it can also diminish spatial and temporal distances. Among other features Interactive Media Art recovered the past relationship to the artistic object, from the tangible experiencing of natural artefacts to the tangible experience of virtual worlds.

After the cabinets of curiosities were replaced by the public museums the dimension of touch in the public institutional context of presentation of Art was almost inexistent. In the museological context, the ZKM's Media Museum, became one where most of the artworks presented request to be touched.

\section{Notes}

[1] It will be often referred to as just ZKM.

[2] The MultiMediale was the Festival of Media Arts that the ZKM organized every two years since 1989 until 1997, the opening of the museums, and it was showing artworks from several proveniences that were adequate to the Media Art program of the Center.

[3] It is not that the designed program for the Center for Art and Media was growing further away from what was planned before. The grounding director of the Institute for Visual Media, Jeffrey Shaw, had already establish a long pathway within the history of Interactive Art, being inclusive one of the pioneers of this art form. Therefore his relation with Interactive Art was sustained by other conceptions that he promptly put into action. By doing so he developed a distinct line of creation. Though always faithful to the relation with the public as interactor, Shaw was also interested in researching for the artistic developments in itself, and about the possibilities given by technology in creating new environments for experimentation and interaction. There was no

ICONO14 | Año 2014 Volumen 12 N² 2 | ISSN: 1697-8293 | DOI: ri14.v12i2.709 
specific plan in creating a continuation with the pedagogical line inaugurated with the ideas of the Konzep ' 88 and followed in a certain way by Heinrich Klotz. Naturally and without significant ruptures Interactive Media Art defined its own place without having to be strictly dependent of a didactic approach.

[4] I refer here one of the first known theoretical approaches to the spectator in the context of Interactive Art and that it was made by Frank Popper in 1975. He sustains: "In fact the term 'spectator' becomes quite inadequate, for we are able to call him executant, actor, user, collaborator and finally creator." (Popper 1975, 10)

[5] Like the works of Söke Dinkla (1994, 1996, 1997), Erkki Huhtamo (1995a, 1995b, 1995c) or the ones from Rudolf Frieling \& Dieter Daniels (1997, 2000).

[6] In the Konzep '88 «Image» had the following subjects: Computer Graphics and Animation; Holography; Video Art and Associated Research (Heck et al., 1988: 18-19). «Music» would deal with: Live-electronic, electroacoustic performances and electroacoustic recordings; Digital Sound Synthesis, Analyses, and Modulation; Electronic Instruments in Combined Formats and Associated Research (Heck et al., 1988: 22-23). «Media for the Citizens» was distributed through different architectural spaces to which would be dedicated different approaches an purposes on transmission of informations, exchange, discussion and mediation, together with the area of Associated Research ((Heck et al., 1988: 26-27).

[7] For the subject «Image» the committee was composed by the following Institutions: the University of Karlsruhe, the Badische Kunstverein, the Academy of Fine Arts of Karlsruhe, the Academy of Fine Arts of Stuttgart, the University of Applied Sciences of Karlsruhe, the Siemens AG of Karlsruhe, the State Association of Artists of Baden-Württemberg, and the University of Cooperative Education of Karlsruhe. For the subject «Music» the committee was composed by the following Institutions: the Academy of Music of Karlsruhe, the Swiss Center for Computer Music, the University of Karlsruhe, the State Association of Educators of Music and Music Artists of the County Music Senate, the Radio Station Süddeutscher Rundfunk of Stuttgat, the Foundation Heinrich-Strobel of SWR of Freiburg, and the University of Cooperative Education of Karlsruhe (Heck et al., 1988: 39)

[8] In all the documents that I have analyzed, and that are the main documents from the foundation of the ZKM, I have not found any reference to the E.A.T.

[9] Besides the services, where citizens could gather informative aspects - which included a library, an audio and video collections accessible to the public, an archive of photography, holography and software and telecommunications -, and besides the workshop rooms - special equipped and where seminars and conferences would take place -, or the laboratories - open to expert citizens and professionals of new technologies, prone to discussion and interaction with the apparatus -, there was the Forum, that alongside with a general exhibition room for films and videos, conferences and events - that is, presentation and information - , was destined to let interactivity with the artwork take shape.

[10] They were viewed as the central element of ZKM. There it was possible to develop experimentation and research between artists, technicians and scientists; image and Music would be under scrutiny and would be subject to interdisciplinary approaches. Specialized technicians and computer scientists would also be included in these creative environment contributing

DOI: ri14.v12i2.709 | ISSN: 1697-8293 | Año 2014 Volumen 12 Nº 2 | ICONO14 
together for the foundation of the artistic practice. The studios could also be used by the citizens in the context of educational tutorials, seminars, and workshops.

[11] Which was considered a central structure of presentation and discussion and would present the results from the work in the laboratories as well as the productions of invited artists from the international scene.

[12] Such follows the advice of Bernhard Graf, from the Institute for Science Museums in Berlin already visited in the paper.

[13] This affirmation in not totally right. There were already other Interactive Media Art artworks by then. Simply they were not that known.

\section{References}

Behringer, P. et al. (1988). ZKM - Zentrum für Kunst und Medientechnologie Karlsruhe. Anlagen zum Konzept '88. Karlsruhe: Comtat T.A. Troga.

Brouwer, J. \& Mulder, A. (2007). Interact or Die! Rotterdam: V2/ NAi.

Candy, L. \& Edmonds, E. (2011). Interacting. Art, Research and the Creative Practitioner. UK: Libri.

Classen, C. (2005). Touch in the Museum. The Book of Touch. Oxford/ New York: Berg, 275-285.

Dinkla, S. (1994). The History of the Interface in Interactive Art. www. kenfeingold.com/dinkla_history.html

Dinkla, S. (1996). From Participation to Interaction: Toward the Origins of Interactive Art. Clicking In: Hot Links to a Digital Culture. Seattle: Bay Press, 279-290.

Dinkla, S. (1997). Pioniere Interaktiver Kunst Von 1970 Bis Heute: Myron Krueger, Jeffrey Shaw, David Rokeby, Lynn Hershman, Grahame Weinbren, Ken Feingold. Ostfildern: Cantz.

Frieling, R. \& Daniels, D. (1997). Medien Kunst Aktion: Die 60er Und 70er Jahre in Deutschland / Media Art Action: The 1960s and The 1970s in Germany. Viena/ Nova Iorque: Springer.

Frieling, R. \& Daniels, D. (2000). Medien Kunst Interaktion: Die 80er Und 90er Jahre in Deutschland / Media Art Action: The 1980s And The 1990s in Germany. Viena/ Nova Iorque: Springer.

Heck, M. et.al. (1988), Konzep '88. Stadt Karlsruhe, 24. März 1988. Karlsruhe: Leibold GmbH.

ICONO14 | Año 2014 Volumen 12 Nº 2 | ISSN: 1697-8293 | DOI: ri14.v12i2.709 
Hein, H. (1993). Naturwissenschaft. Kunst und Wahrnehmung. Der neue Museumstyp aus San Francisco. Stuttgart: Klett-Cotta.

Huhtamo, E. (1995a). The Crank, The Push-button And The Marvels of Digitalia Towards an Archeology of Interactivity. www.interstanding.ee/il/huhtamo.html Huhtamo, E. (1995b). Resurrecting the Technological Past: An Introduction to the Archeology of Media Art. www.ntticc.or.jp/pub/ic_mag/ic014/huhtamo/ huhtamo_e.html

Huhtamo, E. (1995c). Seeking Deeper Contact: Interactive Art as Metacommentary. www.kenfeingold.com/artworks90s.html

Huhtamo, E. (2007). Twin-Touch-Test-Redux: Media Archeological Approach to Art, Interactivity, and Tactility. MediaArtHistories, Cambridge/ Massaschusstes: MIT Press, 71-101.

Klotz, H. (1989). Programm Zentrum für Kunst und Medientechnologie und Hochschule für Gestaltung Karlsruhe. Ergänzende Ausführungen zum "Konzep '88". Karlsruhe: Stadt Karlsruhe.

Klotz, H. (1990). Zentrum für Kunst und Medientechnologie Karlsruhe. Ein Architektur Wettbewerb. Stuttgart-München: Oktogon.

Kwastek, K. (2013). Aesthetics of Interaction in Digital Art. Cambridge/ London: MIT Press.

Popper, F. (1975). Art, Action and Participation. London: Studio Vista, 10.

Seifert, U., Kim, J.H. \& Moore, A. (2008). Paradoxes of Interactivity: Perspectives for Media Theory, Human-Computer Interaction, And Artistic Investigations. Bielefeld: Transcript.

Sommerer, C. et al. (2008). Interface Cultures: Artistic Aspects of Interaction. New Brunswick/ Londres: Transaction Publishers.

Späth, L. et al. (1990). Medienkunst 90. Jahrbuch der Gesellschaft zur Förderung der Kunst und Medientechnologie E.V. Karlsruhe: G. Braun.

ZKM (1989). Be-greifen und Verstehen: Techno-Kultur in USA und Frankreich. Karlsruhe: ZKM.

ZKM (1989). MultiMediale 1. Karlsruhe: ZKM. ZKM (1991). MultiMediale 2. Karlsruhe: ZKM. ZKM (1993). MultiMediale 3. Karlsruhe: ZKM. ZKM (1995). MultiMediale 4. Karlsruhe: ZKM. ZKM (1997). MultiMediale 5. Karlsruhe: ZKM.

DOI: ri14.v12i2.709 | ISSN: 1697-8293 | Año 2014 Volumen 12 № 2 | ICONO14 